\title{
Weapons inspections challenge pharma industry
}

As United Nations Special Commission (UNSCOM) inspectors start to resume the biological weapons monitoring system in Iraq, negotiators at the UN in Geneva are trying to come up with a legally binding instrument to strengthen the Biological Weapons Convention. And that move could have important repercussions for the pharmaceuti$\mathrm{cal}$ and biotechnology companies involved in microbial and cell culture.

The special commission overseeing Irag was set up in 1991 by the Security Council after the Gulf war as part of the cease-fire agreement. It requires Iraq to disclose full details of its offensive biological weapons program (as well as chemical and nuclear programs), and allows UNSCOM inspectors to supervise the destruction of proscribed weapons and facilities, and to establish a monitoring system to ensure that dual-use equipment is not misused for prohibited purposes.

The monitoring program was disrupted when equipment was moved around during a time when UNSCOM inspectors were out of the country last November, making it necessary that inspectors recheck the location of 893 tagged items at the 90 biological sites monitored in Iraq. Although UNSCOM inspectors execute a very comprehensive monitoring system, the main problem is the "dual use" nature of biotechnology equipment; facilities for the production of biological agents closely resemble facilities used for "legitimate" purposes such as vaccine production.

"I think biological weapons are a very real threat," says Graham Pearson, former director general of the UK Government Chemical and Biological Defense Establishment at Porton Down, and visiting professor of international security at Bradford University, UK. "This is why the ongoing negotiations in Geneva to strengthen the Biological and Toxic Weapons Convention are so important."

Although biological weapons are easier and cheaper to make than chemical or nuclear weapons, the international treaty and legislation prohibiting them is the weakest. The Biological Weapons Convention-an international treaty agreed in 1972, to "control the spread of biological weapons"-has no enforcement measures and "was originally really a 'gentleman's agreement," according to Jack Melling of the Salk Institute (Swiftwater, PA) and exdirector of the Center for Applied Microbiology Research (Porton Down, UK), explaining that the Biological Weapons Convention has been overtaken by the Chemical Weapons Convention (CWC). Matthew Meselson, professor of molecular and cellular biology at Harvard University (Cambridge, MA), a long-time advocate of tighter biological weapons control agrees, "The Chemical Weapons Convention has verification provisions, including inspections of declared facilities and also challenge inspections. The Biological Weapons Convention has neither."

According to Melling, the CWC, which came into force last April, provides a good model of an effective treaty. Although there is always the possibility of industrial espionage by an international inspection team, the CWC managed to address the question of

\section{"Legal use of [biotechnolo- gy] equipment should not be put on the line.... We don't want [to be used] as political pawns."}

confidentiality during facility inspections because the chemical industry associations were very supportive of the CWC and worked hard to bring it into being. (The provisions of the CWC apply also to the pharmaceutical industry facilities.)

One of the key points of the continuing discussions in Geneva, according to Meselson, is the question of inspections at declared industrial facilities that have certain dual-use equipment. The idea is that all parties that sign the convention will declare such sites, which will then be subject to occasional on-site visits.

However, there is concern, particularly among representatives of the US pharmaceutical industry, that a system of routine industrial inspections could breach proprietary information. Gillian Woollett, assistant vice president of biologics and biotechnology at the Pharmaceutical Research and Manufacturers of America (PhRMA; Washington, DC) says that PhRMA wants on-site visits limited to challenge inspections supported by evidence that the treaty has been violated. "Legal use of [biotechnology] equipment should not be put on the line ... We don't want [parties] using us [pharma industry] as political pawns to get at the US or any government."

Informed sources believe that the US government may be hiding behind PhRMA-if the association was not objecting so loudly, they say, the current interagency disagreements on the matter would have to be resolved so that the US government could make a biological-weapons policy decision.

One obstacle to strengthening the Biological Weapons Convention is the conflict between article $\mathrm{X}$ of the treaty-which requires countries to cooperate in transferring technology for peaceful purposes-and article III-which prohibits technology transfer to countries for prohibited purposes. Strengthening article $\mathrm{X}$ - the aim of the poorer countries-would help the growth of biotechnology industry, while strengthening article III- the aim of developed nationswould inhibit the spread of biological weapons. The challenge in Geneva is to devise a regime that achieves both of these goals.

Although the US has no official position on the question of inspections, as Meselson puts it, both government and industry in the UK believe that "[visits to declared facilities] would have benefits exceeding their costs."

Melling, who was involved in practice inspections in the UK, considers that it is difficult for inspectors not to learn commercial secrets. He points out, however, that pharmaceutical companies already undergo inspections from such agencies as the US Food and Drug Administration (Rockville, MD) and the European Medicines Evaluation Agency (London) and by agencies responsible for for health, safety, and environmental protection. "UNSCOM [-style investigations] are not likely to be paralleled in the [biological weapons] conventions because of the severity of the intrusiveness involved," says Malcolm Dando, professor of peace studies at Bradford University (Bradford, UK), "However, UNSCOM has been a success and shows what can be done in a strengthened biological weapons convention."

"Challenge inspections as a process clearly have the potential to detect and deter," says Ewan Buchanan of UNSCOM. However, he points out that although UNSCOM inspectors had far-reaching rights to inspect Iraqas well as lots of help from government suppliers-it still took UNSCOM four years to amass enough evidence to get Iraq to concede the existence of a biological weapons program.

Alistair Hay, reader in chemical pathology at Leeds University (Leeds, UK) suggests the pharmaceutical industry simply hasn't yet come to terms with the stigma associated with potential biological weapons. Biological weapons of mass destruction have never actually been used, and the companies are trying to distance themselves from them. "There is some optimism in Geneva that biotechs and pharmaceuticals can be just as supportive [as the chemical companies were].... It is in their interest to have a clean bill of health," says Nicholas Sims, senior lecturer in international relations at the London School of Economics.

Emma Dorey 